\title{
Anammox biofilm process using sugarcane bagasse as an organic carrier
}

\author{
Zulkarnaini", Puti Sri Komala, Arief Almi \\ Department of Environmental Engineering, Limau Manis, Kec. Pauh, Kota Padang, Sumatera Barat 25175, Indonesia \\ ${ }^{*}$ Corresponding author: zulkarnaini@eng.unand.ac.id
}

SUBMITTED 12 August 2020 REVISED 29 November 2020 ACCEPTED 31 December 2020

\begin{abstract}
The anaerobic ammonium oxidation (anammox) biofilm process commonly uses various inorganic carriers to enhance nitrogen removal under anaerobic conditions. This study aims to analyze the performance of nitrogen removal in the anammox process using sugarcane bagasse as an organic carrier. The experiment was carried out by using an up-flow anaerobic sludge blanket (UASB) reactor for treating artificial wastewater at room temperature. The reactor was fed with ammonium and nitrite with concentrations of $70-150 \mathrm{mg}-\mathrm{N} / \mathrm{L}$ and variations in the hydraulic retention time of 24 and 12 h. The granular anammox belongs to the genus Candidatus Brocadia sinica that was added as an inoculum of the reactor operation. The experimental stoichiometric of anammox for $\Delta \mathrm{NO}_{2}{ }^{-}-\mathrm{N}: \Delta \mathrm{NH}_{4}{ }^{+}-\mathrm{N}$ and $\Delta \mathrm{NO}_{3}{ }^{-}: \Delta \mathrm{NH}_{4}{ }^{+}$were 1.24 and 0.18 , respectively, which is similar to anammox stoichiometry. The maximum Nitrogen Removal Rate (NRR) has achieved 0.29 $\mathrm{kg}-\mathrm{N} / \mathrm{m}^{3}$.d at Nitrogen Loading Rate (NLR) $0.6 \mathrm{~kg}-\mathrm{N} / \mathrm{m}^{3}$.d. The highest ammonium conversion efficiency (ACE) and nitrogen removal efficiency (NRE) were $88 \%$ and $85 \%$, respectively. Based on these results, it indicated that sugarcane bagasse as organic carriers could increase the amount of total nitrogen removal by provided of denitrification process but inhibited the anammox process at a COD: $\mathrm{NO}_{2}{ }^{-}-\mathrm{N}$ ratio of 2.02 .
\end{abstract}

KEYWORDS Anammox; sugarcane bagasse; room temperature

\section{Introduction}

The sources of nitrogen pollution come from domestic and non-domestic wastewater. Non-domestic wastewaters, such as electroplating, fertilizer, and tannery industries, produce the wastewater which contains high ammonium content. The nitrogen pollutions from fertilizer, industrial wastewater, animal and human organic waste, increase the amount of ammonium concentration on the water surface. Together with other nutrients, high nitrogen concentration promotes eutrophication in receiving water bodies.

The process of nitrogen removal from wastewater could be carried out by various physical, chemical, and biological processes. In general, nitrogen removal is physically conducted by the adsorption process, while the biological nitrogen removal is considered for more effective and relatively inexpensive process, also it has been widely used to support physical processes (Ahn 2006). The conventional nitrificationdenitrification method is generally applied for nitrogen removal for high carbon/nitrogen $(\mathrm{C} / \mathrm{N})$ containing wastewater. In the nitrification-denitrification process, ammonia is oxidized to nitrate under aerobic conditions, then nitrate is converted to dinitrogen gas using organic carbon as an electron acceptor (Jin et al. 2012). However, the con- ventional nitrification-denitrification increases in operating expenses since it entails complete aeration, additional organic carbon such as methanol, and a large amount of sludge waste (Ali and Okabe 2015).

Anammox was discovered in the 1990s at TU-Delft, Netherlands and nitrite is used as an electron acceptor in converting ammonium to nitrogen gas in this process (Van De Graaf et al. 1996). Anammox is an innovative technology to biological nitrogen removal compared to conventional nitrification-denitrification, due to a higher nitrogen removal rate (NRR), lower operating costs, and no extra space required. In addition, the operation of anammox process is enabled to reduce $64 \%$ aeration, no organic carbon required, and less sludge waste (Ali and Okabe 2015).

The anammox process was applied on a laboratory, pilot, and full-scale for ammonium-rich wastewater treatment, such as leachate landfill, industrial and pharmaceutical wastewaters, and other types of wastes (Lackner et al. 2014). Various variations of anammox research have been applied, such as type of reactors, membrane bioreactor (MBR), fluidized bed reactor, sequencing batch reactor (SBR), up-flow anaerobic sludge blanket (UASB) and other modifications (Kumar et al. 2016). However, the UASB reactor has advantages compared to other reactors since no extra space is required and low construction and operating costs (Nathan and Scobell 2012). 
TABLE 1 Composition of artificial wastewater.

\begin{tabular}{lllllllll}
\hline \multirow{2}{*}{ Reactor } & \multicolumn{2}{l}{ Artificial Wastewater (mg/L tap water) } & & \multicolumn{2}{c}{ Trace Element (ml/L tap water) } \\
\cline { 2 - 9 } & $\mathrm{NH}_{4}{ }^{+}-\mathrm{N}$ & $\mathrm{NO}_{2}{ }^{-}-\mathrm{N}$ & $\mathrm{KH}_{2} \mathrm{PO}_{4}$ & $\mathrm{MgSO}_{4} .7 \mathrm{H}_{2} \mathrm{O}$ & $\mathrm{CaCl}_{2} \cdot \mathrm{H}_{2} \mathrm{O}$ & $\mathrm{KHCO}_{3}$ & $\mathrm{I}$ & $\mathrm{II}$ \\
\hline UASB & $70-150$ & $70-150$ & 27.2 & 300 & 180 & 500 & 1 & 1 \\
\hline
\end{tabular}

Inorganic supporting carrier is used to enhance nitrogen removal in anammox biofilm processes, such as nonwoven (Gao et al. 2012), string wound filter (Zulkarnaini et al. 2018), and polyvinyl alcohol and sodium alginate (PVA-SA) gel bead (Tuyen et al. 2018). Utilization of inorganic carrier is preferred to prevent the growth of heterotrophic bacteria that uses organic material as electron acceptors. Consequently, the fast growth heterotrophic bacteria eliminate the slow-growing rate (the maximum specific growth rate $=0.0027 / \mathrm{h}$ ) anammox bacteria which has a doubling time of 10-12 d (Jetten et al. 1998). In addition, carbon as an organic matter is also one of the parameters for the anammox inhibition process. Anammox bacteria is a chemoautotrophic microorganisms that utilize $\mathrm{CO}_{2}$ as the only carbon source (Strous et al. 1999). Therefore, the composition of substrate contained bicarbonate for the anammox process is important for the cultivation of anammox bacteria. The activity of anammox increased as the influent bicarbonate concentration rose from 1.0 to $1.5 \mathrm{~g} / \mathrm{L}$, and inhibited at $2.0 \mathrm{~g} / \mathrm{L}$ (Liao et al. 2008).

Chen et al. (2012) reported that organic media, such as hollow bamboo sphere media and bamboo charcoal, is enable to accelerate the start-up of the anammox process. The existence of organic carbon could enhance nitrogen removal together with the denitrificatoin process where nitrate converts to nitrogen gas in anaerobic condition. Nitrate is another product of the anammox process instead of nitrogen gas; therefore, a small amount of organic carbon could promote simultaneous anammox-denitrification process for nitrogen removal. The palm fiber has been used as a carrier for nitrogen removal by anammox process with the maximum nitrogen removal rate (NRR) of 0.20 $\mathrm{kg}-\mathrm{N} / \mathrm{m}^{3}$.d at NLR $0.29 \mathrm{~kg}-\mathrm{N} / \mathrm{m}^{3}$.d (Zulkarnaini et al. 2019). Therefore, organic material has the potential as a carrier in the anammox biofilm process for reducing the unuseful waste materials including various organic materials that are abundance in the environment.

In Indonesia, sugarcane is one of the major agricultural commodities with a plantation area of about 415.66 thousand hectares (BPS 2018). The agricultural product of sugarcane is used as a raw material in the sugar industry, however, it produces waste in the form of sugarcane bagasse in the production process. Sugarcane bagasse is insoluble because this material consists of cellulose, pentosan, and lignin (Allita et al. 2018). Therefore, in this research, sugarcane bagasse media was used as a carrier for facilitating the formation of biofilm in the nitrogen removal process. In this study, sugarcane bagasse is used in the UASB reactor for removing nitrogen content in wastewater through the anammox process.

\section{Materials and Methods}

\subsection{Preparation of inoculum, organic carrier, and arti- ficial wastewater}

Granular anammox Candidatus Brocadia sinica from Kanazawa University, Japan, was used as inoculum for start-up of the reactor (Zulkarnaini et al. 2020). Previously, the cultivation anammox reactor was incubated at $35^{\circ} \mathrm{C}$ where the growth temperature in the range $25-45^{\circ} \mathrm{C}$ (Awata et al. 2013). Before starting the experiment, the bacteria were acclimatized at room temperature for three months. During the acclimatization process, anammox bacteria were fed with ammonium and nitrite.

Sugarcane bagasse in sheet form was used as a carrier to grow anammox biofilm and filled $25 \%$ in the reactor's volume. The eight sheets sugarcane bagasse carrier with dimension $15 \mathrm{~cm}$ length, $3.2 \mathrm{~cm}$ wide, and $0.2 \mathrm{~cm}$ thickness were filled vertically into the reactor to increase the contact surface area of the anammox process. Therefore the anammox process is not only occurred at the bottom of the reactor.

The artificial wastewater was designed with medium containing (per L) $\mathrm{KHCO}_{3}, 500$ mg; $\mathrm{KH}_{2} \mathrm{PO}_{4}, 27.2 \mathrm{mg}$; $\mathrm{MgSO}_{4} .7 \mathrm{H}_{2} \mathrm{O}, 300 \mathrm{mg} ; \mathrm{CaCl}_{2} .2 \mathrm{H}_{2} \mathrm{O}, 180 \mathrm{mg}$; trace element solution I (per liter of distillate water contained EDTA 2Na $6.37 \mathrm{~g} ; \mathrm{FeSO}_{4} 5 \mathrm{~g}$ ), and trace element solution II (per liter of distillate water contained EDTA $2 \mathrm{Na}$ 19.11 g; $\mathrm{ZnSO}_{4} 0.241 \mathrm{~g} ; \mathrm{CoCl} .6 \mathrm{H}_{2} \mathrm{O} 0.24 \mathrm{~g} ; \mathrm{MnCl}_{2} .4 \mathrm{H}_{2} \mathrm{O}$ 0.99 g; $\mathrm{CuSO}_{4} .5 \mathrm{H}_{2} \mathrm{O} 0.25$ g; $\mathrm{NaMnO}_{4} .2 \mathrm{H}_{2} \mathrm{O} 0.22$ g; $\mathrm{NiCl}_{2} \cdot 6 \mathrm{H}_{2} \mathrm{O} 0.19$ g; $\mathrm{NaSeO}_{4} \cdot 10 \mathrm{H}_{2} \mathrm{O} 0.024$ g; $\mathrm{H}_{3} \mathrm{BO}_{4}$ $0.014 \mathrm{~g})$. The substrate supplemented with $(\mathrm{NH})_{2} \mathrm{SO}_{4}$ and $\mathrm{NaNO}_{2}$ was fed into the reactor continuously (Table 1). During the medium preparation, the substrate was purged with nitrogen gas $\left(\mathrm{N}_{2}\right)$ for $30 \mathrm{~min}$ to remove the oxygen.

\subsection{Reactor configuration and operation condition}

The $300 \mathrm{~mL}$ acrylic UASB reactor was conducted for this experiment. The substrate was delivered through the bottom of the reactor using a peristaltic pump. To assure anaerobically condition, the tank of the substrate was

TABLE 2 Variation of influent concentration and hydraulic retention time.

\begin{tabular}{lllll}
\hline Period & $\mathrm{HRT}(\mathrm{h})$ & $\begin{array}{l}\mathrm{NH}_{4}{ }^{+}-\mathrm{N} \\
(\mathrm{mg} / \mathrm{L})\end{array}$ & $\begin{array}{l}\mathrm{NO}_{2}{ }^{-} \mathrm{N} \\
(\mathrm{mg} / \mathrm{L})\end{array}$ & $\mathrm{NLR}\left(\mathrm{kg}-\mathrm{N} / \mathrm{m}^{3} . \mathrm{d}\right)$ \\
\hline $\mathrm{I}$ & 24 & 70 & 70 & 0.14 \\
$\mathrm{II}$ & 12 & 70 & 70 & 0.28 \\
$\mathrm{III}$ & 12 & 150 & 150 & 0.60 \\
\hline
\end{tabular}


equipped with a gas bag containing $\mathrm{N}_{2}$ gas. The reactor operated in three periods, with various concentrations of artificial wastewater, $70-150 \mathrm{mg}-\mathrm{N} / \mathrm{L}(\mathrm{NH})_{2} \mathrm{SO}_{4}$ and $\mathrm{NaNO}_{2}$, and hydraulic retention time (HRT) of $24 \mathrm{~h}$ and $12 \mathrm{~h}$. The operation condition can be seen in Table 2.

\subsection{Calculation of nitrogen removal performance}

Anammox reactor performance was calculated based on nitrogen balance. Ammonium Conversion Efficiency (ACE,\%), Nitrogen Removal Efficiency (NRE,\%), Nitrogen Loading Rate (NLR, kg-N/m ${ }^{3}$.d) and Nitrogen Removal Rate (NRR, kg-N/m ${ }^{3}$.d) were calculated based on the Equation 1, 2, 3, and 4 (Zulkarnaini et al. 2019).

$$
\begin{aligned}
& A C E(\%)=\frac{i n f\left[\mathrm{NH}_{4}^{+}-\mathrm{N}\right]-\operatorname{eff}\left[\left[\mathrm{NH}_{4}^{+}-\mathrm{N}\right]\right.}{\inf \left[\mathrm{NH}_{4}^{+}-\mathrm{N}\right]} \times 100 \%
\end{aligned}
$$

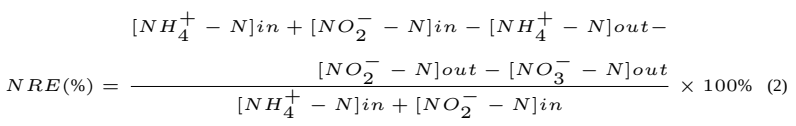

$$
\begin{aligned}
& {\left[\mathrm{NH}_{4}^{+}-\mathrm{N}\right] \mathrm{in}+\left[\mathrm{NO}_{2}^{-}-\mathrm{N}\right] \mathrm{in}-} \\
& {\left[\mathrm{NH}_{4}^{+}-\mathrm{N}\right] \text { out }-\left[\mathrm{NO}_{2}^{-}-\mathrm{N}\right] \mathrm{out}-} \\
& N R R\left(\mathrm{~kg}-\mathrm{N} / \mathrm{m}^{3} \cdot \mathrm{d}\right)=\frac{\left[\mathrm{NO}_{3}^{-}-\mathrm{N}\right] \mathrm{out}}{\mathrm{HRT}} \times \frac{24}{1000}
\end{aligned}
$$

\section{Results and Discussion}

\subsection{Anammox stoichiometry}

Anammox process in the reactor can be observed from the molar ratio of $\Delta \mathrm{NO}_{2}{ }^{-}-\mathrm{N} / \Delta \mathrm{NH}_{4}{ }^{+}-\mathrm{N}$ to produce $\mathrm{N}_{2}$ and $\mathrm{NO}_{3}{ }^{-}$(Hu et al. 2017), based on the stoichiometry of the anammox process defined by Strous et al. (1997) (Equation 4) and Lotti et al. (2014) (Equation 5).

$$
\begin{array}{r}
\mathrm{NH}_{4}^{+}+1.32 \mathrm{NO}_{2}^{-}+0.066 \mathrm{HCO}_{3}^{-}+0.13 \mathrm{H}^{+} \rightarrow \\
1.02 \mathrm{~N}_{2}+0.26 \mathrm{NO}_{3}^{-}+0.066 \mathrm{CH}_{2} \mathrm{O}_{0.5} \mathrm{~N}_{0.15}+2.03 \mathrm{H}_{2} \mathrm{O} \\
\mathrm{NH}_{4}^{+}+1.146 \mathrm{NO}_{2}^{-}+0.071 \mathrm{HCO}_{3}^{-}+0.057 \mathrm{H}^{+} \rightarrow \\
0.986 \mathrm{~N}_{2}+0.161 \mathrm{NO}_{3}^{-}+0.071 \mathrm{CH}_{2} \mathrm{O}_{0.5} \mathrm{~N}_{0.15}+2.002 \mathrm{H}_{2} \mathrm{O}
\end{array}
$$

The ratio of nitrite consumption to ammonium consumption $\left(\Delta \mathrm{NO}_{2}{ }^{-}-\mathrm{N}: \Delta \mathrm{NH}_{4}{ }^{+}-\mathrm{N}\right)$ and the ratio of nitrate production to ammonium consumption $\left(\Delta \mathrm{NO}_{3}{ }^{-}-\mathrm{N}\right.$ : $\Delta \mathrm{NH}_{4}{ }^{+}-\mathrm{N}$ ) were calculated from the conversion of ammonium, nitrite, and produced nitrate. The average of the ratio $\Delta \mathrm{NO}_{2}{ }^{-}-\mathrm{N}: \Delta \mathrm{NH}_{4}{ }^{+}-\mathrm{N}$ obtained from the experiment at stable period (12-75 d operation) was 1.16 molar. Based on Figure 2, the ratio $\Delta \mathrm{NO}_{2}{ }^{-}-\mathrm{N}: \Delta \mathrm{NH}_{4}{ }^{+}-\mathrm{N}$ is similar to the ratio defined by Lotti et al. (2014). Reduction of ammonium and nitrite simultaneously indicated that one of the products of the anammox process, instead of nitrogen gas, is a small amount of nitrate $\left(\mathrm{NO}_{3}{ }^{-}\right)$(Tsushima et al. 2007). In Figure 3, it showed the ratio of $\Delta \mathrm{NO}_{3}{ }^{-}-\mathrm{N}: \Delta \mathrm{NH}_{4}{ }^{+}-\mathrm{N}$ during this studies, the average of $\Delta \mathrm{NO}_{3}{ }^{-}-\mathrm{N}: \Delta \mathrm{NH}_{4}{ }^{+}-\mathrm{N}$ obtained was 0.18 , relatively similar to Lotti et al. (2014). At the beginning of the operation, the ratio of $\Delta \mathrm{NO}_{3}{ }^{-}-\mathrm{N}$ : $\Delta \mathrm{NH}_{4}{ }^{+}-\mathrm{N}$ was higher than stoichiometry of anammox reaction. This result tends to decrease and be lower than the stoichiometric until the end of the experiment. It could be a simultaneous anammox-denitrification process for nitrogen removal where nitrate produced by the anammox process is converted into $\mathrm{N}_{2}$ in the presence of organic carbon originated from sugarcane bagasse. In agreement with the previous report that the application of sugarcane bagasse enhanced the nitrogen removal, thus this process can be developed for wastewater treatment (Li et al. 2016).

The difference of value ratio in Strous and Lotti's stoichiometry is occurred due to the different anammox process operation, such as the type of reactor, species of anammox bacteria, the form of biomass (granule or biofilm) and temperature in operation. Strous et al. (1997) used SBR with granular bacteria at an optimum temperature of $32-33^{\circ} \mathrm{C}$. In comparison, Lotti et al. (2014) used an MBR with biofilm-shaped bacteria at a temperature of $30^{\circ} \mathrm{C}$. This study is relatively similar to Lotti et al. (2014), although it used a different UASB reactor, both are continuous operation.

In this study, the temperature also affects the anammox process. The range of temperature during the whole

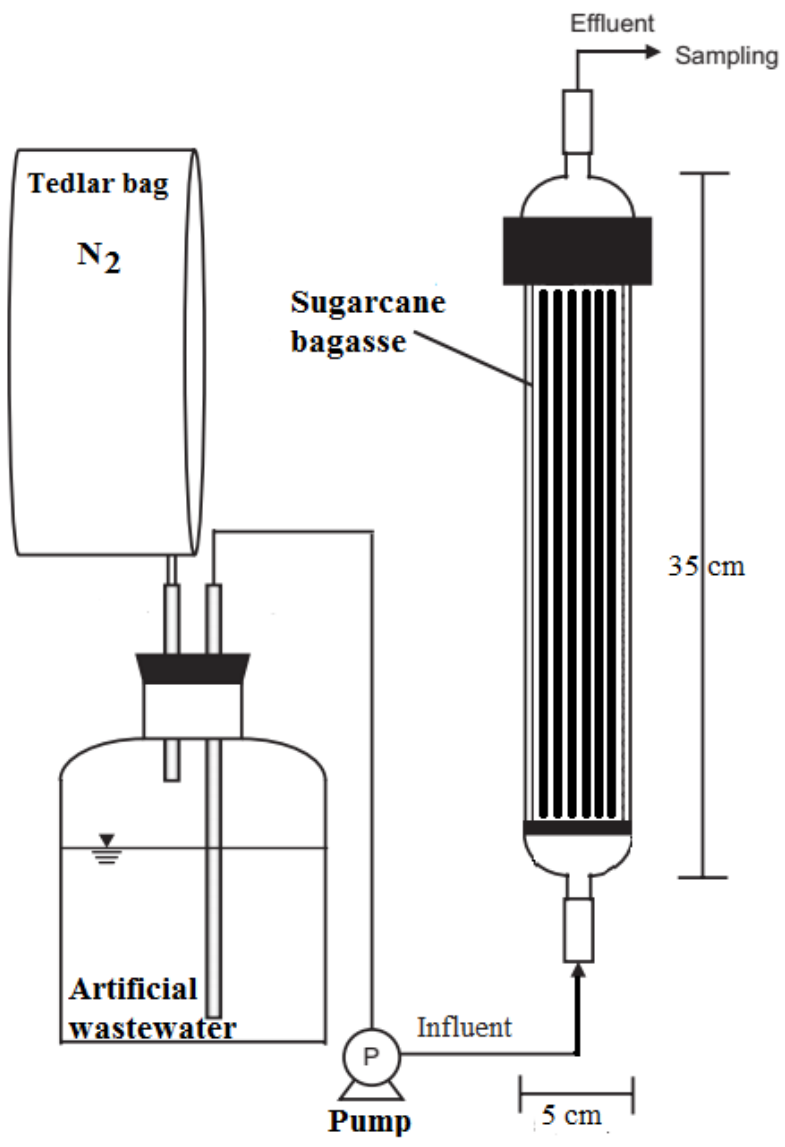

FIGURE 1 Reactor configuration of UASB anammox biofilm. 


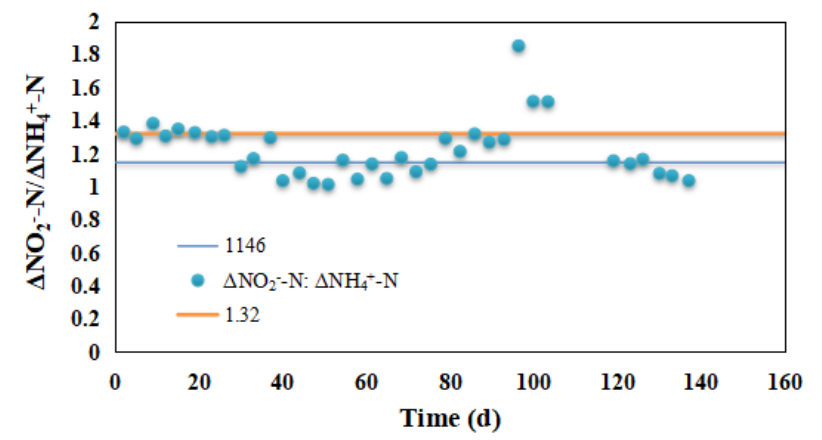

FIGURE 2 Ratio of $\Delta \mathrm{NO}_{2}{ }^{-}-\mathrm{N} / \Delta \mathrm{NH}_{4}{ }^{+}-\mathrm{N}$ compared to the stoichiometry of anammox. The ratio of 1.32 defined by Strous et al. (1997) and 1.146 by Lotti et al. (2014).

operation was $23-28^{\circ} \mathrm{C}$, in the range activity of anammox bacteria of $25-45^{\circ} \mathrm{C}$ where the optimum performance of Candidatus Brocadia sinica was conducted at $35-40{ }^{\circ} \mathrm{C}$ (Oshiki et al. 2011). Therefore, the lower temperature operation will decrease the performance of anammox for removing nitrogen. However, the result of the nitrogen conversion ratio indicated the anammox process has occurred in the reactor.

\subsection{Profile of nitrogen concentration in UASB reactor operation}

The anammox process took place from the beginning of the study, where the ammonium and nitrite conversion occurred under anaerobic conditions. In this study, anammox bacteria of the Candidatus Brocadia sinica species were used as inoculum since it was adapted to environmental temperatures in Indonesia. The use of pure anammox bacteria accelerates the time of the start-up anammox process in nitrogen removal in wastewater compared to using activated sludge containing various types of organisms. The abundance of anammox bacteria in the environment is very small compared to other bacteria due to the slow growth rate. The experience of the world's first large-scale anammox reactor in the Netherlands took more than 3.5 years for the start-up process with high nitrogen removal performance (van der Star et al. 2007).

In the first three weeks of reactor operation, ammonium and nitrite concentration were relatively stable in the range 41-49 mg-N/L and 32-40 mg-N/L, respectively. Simultaneous conversion of ammonium and nitrite in anaerobic conditions without organic carbon is an indication of the anammox process, which distinguishes it from the nitrification-denitrification process and takes place in aerobic process. One of the disadvantages of selecting this anammox bacteria is classified as slow growth rate bacteria, thus generating the anammox process is also getting slower. The doubling time of anammox bacteria is between 7-14 d. However, the growth time of Candidatus Brocadia sinica can be accelerated to $2.1 \mathrm{~d}$ using an up-flow column reactor for cultivation with high substrate loading rates at $37^{\circ} \mathrm{C}$ (Zhang et al. 2017).

Then, the ammonium and nitrite concentrations be-

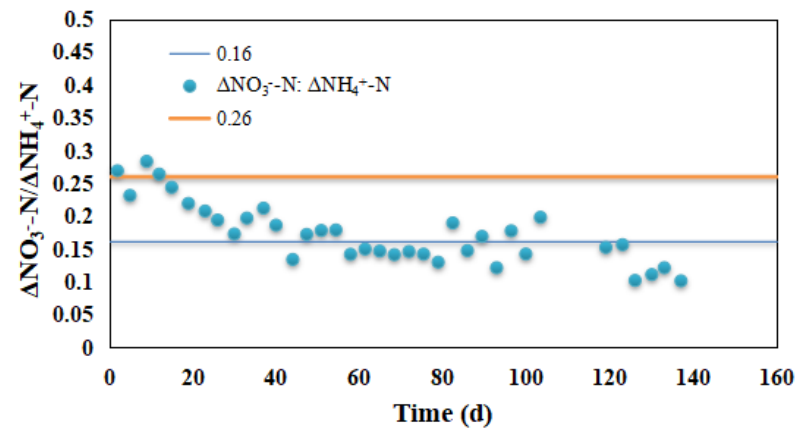

FIGURE 3 Ratio of nitrate production to ammonium consumption $\left(\Delta \mathrm{NO}_{3}{ }^{-}-\mathrm{N} / \Delta \mathrm{NH}_{4}{ }^{+}-\mathrm{N}\right)$. The ratio of 0.26 defined by Strous et al. (1997) and 0.16 by Lotti et al. (2014).

gan to drop simultaneously from $40.48 \mathrm{mg}-\mathrm{N} / \mathrm{L}$ and 29.73 $\mathrm{mg}-\mathrm{N} / \mathrm{L}$ on day 23 to $26.75 \mathrm{mg}-\mathrm{N} / \mathrm{L}$ and $23.08 \mathrm{mg}-\mathrm{N} / \mathrm{L}$ on day 40, respectively. The conversion performance of ammonium and nitrite was stable for $14 \mathrm{~d}$. From day 54 effluent concentrations were in the range 23-29 mg-N/L and 19-26 mg-N/L. The process that undergoes a growth process besides nitrogen conversion by consuming ammonium using nitrite as an electron acceptor was carried out by anammox bacteria. Based on Equation 5, 1 mole of ammonium and 1.146 mole nitrite generate $0.071 \mathrm{~mol}$ biomass. Low biomass production is also one of the advantages of anammox processes that produce less biomass, $0.071 \mathrm{CH}_{2} \mathrm{O}_{0.5} \mathrm{~N}_{0.15}$, as shown in Equation 5. However, the activity of nitrogen conversion is determined by the amount of anammox biomass. Therefore, more anammox biomass is required in order to increase the conversion process. In the reactor, the anammox bacteria carried out the growth process for two weeks following the doubling time of the anammox bacteria, which is 7-14 $\mathrm{d}$.

After multiplying of anammox bacteria, there was a rapid decrease in the concentration of ammonium and nitrite. Almost all ammonium and nitrite were lost from the reactor. At the end of the first period, the concentrations of ammonium and nitrite reached the lowest levels of 8.67 $\mathrm{mg}-\mathrm{N} / \mathrm{L}$ and $3.74 \mathrm{mg}-\mathrm{N} / \mathrm{L}$, respectively. At this stage, the anammox process achieved the maximum performance where almost all substrates were consumed into nitrogen gas. Prevented the limitation of the substrate, which is the food of the growing anammox bacteria, the hydraulic retention time (HRT) decreased from $24 \mathrm{~h}$ to $12 \mathrm{~h}$.

In the whole reactor process, the nitrate does not supplement into the substrate, only ammonium and nitrite. The nitrate contents were detected in the samples effluent with relatively constant concentrations in the range of 7.6-9.6 mg-N/L. The reactor operation was designed in an anaerobic condition and intended into the nitrogen conversion process which is carried out by the anammox process and nitrification inhibition. Based on stoichiometry in Equation 5, the anammox process produces a small nitrate instead of nitrogen gas. Thus, the nitrate produced is a product of the anammox process; the presence of nitrate in anaerobic conditions is an indicator of the anammox pro- 
cess.

In the second period with the $12 \mathrm{~h}$ HRT, there was a further increase in the ammonium and nitrite concentrations in the effluent to $30.60 \mathrm{mg}-\mathrm{N} / \mathrm{L}$ and $19.96 \mathrm{mg}-$ $\mathrm{N} / \mathrm{L}$, respectively. Shock loading occurred when the NLR was increased from $0.14 \mathrm{~kg} / \mathrm{m}^{3}$.d to $0.28 \mathrm{~kg} / \mathrm{m}^{3}$.d. Anammox bacteria supplied with a double loading rate as a result of the nitrogen conversion process back to the initial conditions up to day 93. Effluent concentrations of ammonium and nitrite were in the range $28-31 \mathrm{mg}-\mathrm{N} / \mathrm{L}$ and 17-22 mg-N/L, respectively. A rapid decrease in nitrogen conversion in period two occurred again on day 96 , where the ammonium and nitrite concentrations in effluent increased to $47.95 \mathrm{mg}-\mathrm{N} / \mathrm{L}$ and $29.31 \mathrm{mg}-\mathrm{N} / \mathrm{L}$, respectively. This condition was stable up to day 103 . This phenomenon was unusual since anammox bacteria will adapt to the shock loading that occurs and returns to be stable after one month, then the nitrogen conversion performance will increase again. There could be other parameters that cause these to be happened. If the nitrate concentration was observed in the second period, there was a decrease in the concentration from $8.79 \mathrm{mg}-\mathrm{N} / \mathrm{L}$ to $5.22 \mathrm{mg}-\mathrm{N} / \mathrm{L}$. This is consistent with an increase in ammonium and nitrite, which indicates a decrease in the activity of anammox bacteria. Nitrate concentrations in the effluent were stable until the $89 \mathrm{~d}$ with a range of 6.2-8.4 $\mathrm{mg}-\mathrm{N} / \mathrm{L}$. However, there was a drastic decrease on day 93 from $6.94 \mathrm{mg}-\mathrm{N} / \mathrm{L}$ to $4.7 \mathrm{mg}-\mathrm{N} / \mathrm{L}$, which also indicated a decrease in anammox activity.

One of the reasons for decreasing nitrogen removal activity is the inhibition of the anammox process due to the presence of organic carbon from sugarcane bagasse, which is used as a carrier for anammox bacteria. The next step is to measure the COD to confirm the hypothesis and determine the next steps to overcome the inhibition that occurs.

On day 96, COD analysis was carried out from observe the reactor's $\mathrm{C} / \mathrm{N}$ ratio. Anammox bacteria have a high ability to convert ammonium from wastewater containing low $\mathrm{C} / \mathrm{N}$. Figure 6 shows the $\mathrm{C} / \mathrm{N}$ ratio is higher than the inhibition limit, and it can be ascertained that the inhibition process occurred in the reactor in the presence of organic carbon. COD reaches $140.8 \mathrm{mg} / \mathrm{L}$, while the nitrite concentration is $70 \mathrm{mg} / \mathrm{L}$ so that the $\mathrm{COD} / \mathrm{NO}_{2}{ }^{-}-\mathrm{N}$ ratio becomes 2.02, which exceeds the inhibition threshold. In the next seven days, the maintenance of the reactor operation was carried out at the pump due to the instability of the flow rate, where the substrate flow was slower than the desired HRT of 12 . The concentration of ammonium and nitrite further increased to $150 \mathrm{mg}-\mathrm{N} / \mathrm{L}$ in the influent for overcoming the inhibition due to the high organic matter content in the reactor.

After the concentration of ammonium and nitrite increased up to $150 \mathrm{mg}-\mathrm{N} / \mathrm{L}$, shock loading occurred again. Ammonium and nitrite concentrations raised to $83.61 \mathrm{mg}-$ $\mathrm{N} / \mathrm{L}$ and $75.43 \mathrm{mg}-\mathrm{N} / \mathrm{L}$ at the beginning of period three operation. Unlike the previous conditions, there was a simultaneous decrease in ammonium and nitrite concentrations and an increase in nitrate production until the end of re- actor operations. The anammox process was successfully recovered by lowering the $\mathrm{C} / \mathrm{N}$ ratio below the inhibition threshold.

\subsection{Nitrogen removal performance}

From the beginning of the operation, nitrogen removal was achieved with ammonium and nitrite removal and the presence of produced nitrates. It showed that the anammox process had already taken place in to the reaction. In addition, NRR is a key parameter to the anammox process. The calculation of NRR was shown in Equations 3. NRR value indicated that the level of nitrogen removal calculated based on the difference in the value of loading nitrogen with nitrogen concentration in the effluent divided by retention time. During $75 \mathrm{~d}$ with $24 \mathrm{~h}$ HRT, the NRR value gradually increased with the Nitrogen Loading Rate (NLR) $0.14 \mathrm{~kg}-\mathrm{N} / \mathrm{m}^{3}$.d. The NLR value is the loading of nitrogen during the operation of the anammox process.

At the beginning of the experiment, NRR was 0.049 $\mathrm{kg}-\mathrm{N} / \mathrm{m}^{3}$.d. The low NRR value was due to anammox bacteria having a slow growth rate compared to other types of bacteria such as AOB and NOB. The increased of NRR values always occurred until day 75 , with a maximum NRR value. However, on day 96, NRR is decreased up to $0.11 \mathrm{~kg}-\mathrm{N} / \mathrm{m}^{3}$.d and slowly rose to $0.15 \mathrm{~kg}-\mathrm{N} / \mathrm{m}^{3}$.d until the end of period two. On day 123 (period three), ammonium and nitrite influent concentrations were increased to $150 \mathrm{mg}-\mathrm{N} / \mathrm{L}$, consequently raising NRR to $0.261 \mathrm{~kg}-$ $\mathrm{N} / \mathrm{m}^{3} . \mathrm{d}$ at NLR $0.6 \mathrm{~kg}-\mathrm{N} / \mathrm{m}^{3} . \mathrm{d}$.

Substrate concentrations consist of ammonium and nitrite with each concentration of 70-150 mg-N/L. The efficiency of ammonium removal (ACE) is also one of the parameters to prove that the anammox process has taken place. Based on Equation 1, ACE is calculated based on the percent of the difference between the ammonium loading and the ammonium in the effluent divided by the ammonium loading concentration. At the start of the reactor, only $33 \%$ of the ammonium was oxidized. With increasing time, the efficiency of ammonium conversion also increased. This result is revealed in the data of Figure 4, whereby on day 37 ACE had reached 55\%. Until day 75, the efficiency increased again to reach the maximum ACE in $24 \mathrm{~h} \mathrm{HRT,} \mathrm{88 \% .} \mathrm{In} \mathrm{contrast,} \mathrm{beginning} \mathrm{the} 12 \mathrm{~h} \mathrm{HRT,}$ ACE drops rapidly to $57 \%$ and ranged from 55-61\% until day 93. On day 96, the ACE drops again to $31 \%$ and rose to $56 \%$ after day 119 . On day 120 , the influent concentration was increased to $150 \mathrm{mg}-\mathrm{N} / \mathrm{L}$, and ACE decreased to $44 \%$, then increased gradually to $55 \%$ at end of reactor operation.

The nitrogen removal efficiency (NRE) shows the accuracy in nitrogen removal expressed in percent. The NRE value is calculated based on the percent of the difference between loading nitrogen and nitrogen obtained at the effluent per concentration of ammonium loading. NRE value was also higher by increasing operating time. At the beginning of the operation, NRE was only 34\%, and there was an increase in the following days. The maximum efficiency with $24 \mathrm{~h}$ HRT obtained on day 75 reached $85 \%$. 


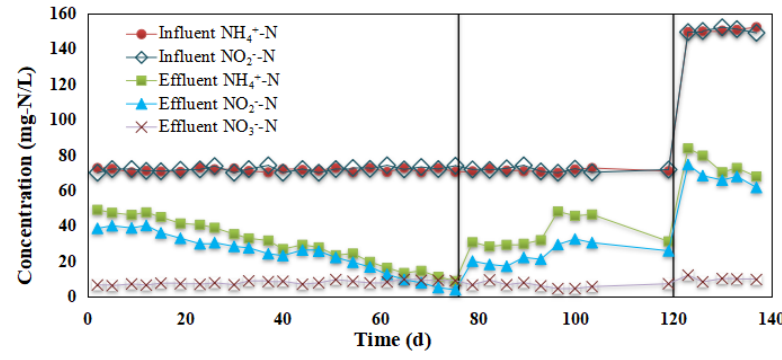

FIGURE 4 Profile of nitrogen during the whole operation of UASB anammox biofilm reactor.

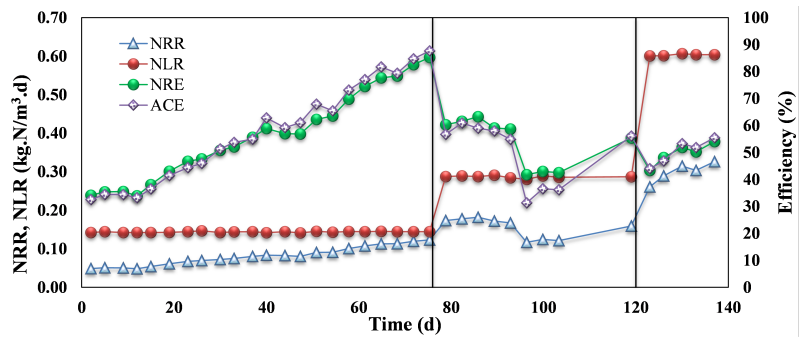

FIGURE 5 Nitrogen removal performance of UASB anammox biofilm reactor.

While the efficiency decreased after HRT was reduced to $12 \mathrm{~h}$, the NRE value obtained was $60 \%$ and ranged from $59-62 \%$ until day 93 . However, on day 96, the NRE value dropped dramatically to $42 \%$. On day 120 , the influent concentration was increased to $150 \mathrm{mg}-\mathrm{N} / \mathrm{L}$, and then, NRE increased gradually to $54 \%$ at the end of period three.

Previous studies have shown that ACE values reached 97.3\%, and NRE reached 97\% in 21 h HRT using the Upflow Biofilter (UBF) reactor (Jin et al. 2008). It also has been proved that the anammox process could remove ammonium up to ACE $92 \%$ and NRE of $94 \%$ using the UASB reactor. When it compared to this study, nitrogen removal has been observed (Ma et al. 2013). The maximum NRR was $0.12 \mathrm{~kg}-\mathrm{N} / \mathrm{m}^{3}$.d at NLR $0.14 \mathrm{~kg}-\mathrm{N} / \mathrm{m}^{3}$.d for HRT 24 $\mathrm{h}$ and $0.17 \mathrm{~kg}-\mathrm{N} / \mathrm{m}^{3}$.d at NLR $0.28 \mathrm{~kg}-\mathrm{N} / \mathrm{m}^{3}$.d for HRT 12 h. NRE and ACE are also directly proportional to NRR, always increasing with time. The maximum NRE and ACE values were $85 \%$ and $88 \%$, respectively, in $24 \mathrm{~h}$ HRT and decreased 55\% and 56\%, respectively, in $12 \mathrm{~h}$ HRT. The decrease in NRR, NRE, and ACE after reduced HRT to 12 $\mathrm{h}$ was due to shock loading, which remarkably increased the pollutant load. However, the anammox process can be applied in the tropical area and proved that anammox bacteria can easily adapt to new environments by acclimatization. However, the decline of bacteria performance in nitrogen removal that occurred on day 96 was caused by high levels of organic matter (COD), thus disrupting the anammox process. Therefore, the influent concentration increased to $150 \mathrm{mg}-\mathrm{N} / \mathrm{L}$ to compensate for the high organic content.

\subsection{Inhibition of anammox process}

One inhibiting factor of the anammox process is the level of organic matter (COD). Chamchoi (2008) reported that

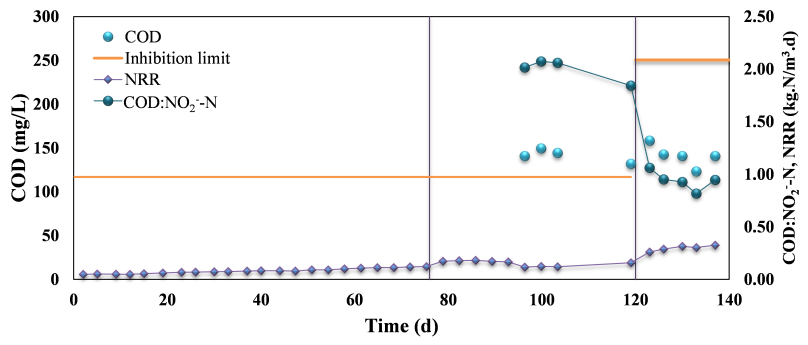

FIGURE 6 Inhibition of anammox process by COD from degradation of sugarcane bagasse.

COD levels that exceed $300 \mathrm{mg} / \mathrm{L}$ cause inactivation of the anammox process. This is similar to Molinuevo et al. (2009) where COD concentrations exceeding $292 \mathrm{mg} / \mathrm{L}$ inhibited the total anammox process. However, according to Tang et al. (2010), the anammox process begins to be hampered when the COD: $\mathrm{NO}_{2}-\mathrm{N}$ ratio is 1.67 , while the anammox process almost does not occur when the ratio of $\mathrm{COD}: \mathrm{NO}_{2}{ }^{-}-\mathrm{N}$ is 2.92. On day 96 , nitrogen removal performance decreased significantly and anammox bacteria experienced partial death indicating the color changed on the sugarcane bagasse. The morphological colors of anammox bacteria with the best performance are bright red or dark red, while bacteria with pale red to black color indicate that there is a decrease in activity or death of bacteria (Ali et al. 2013). After measuring the COD on day 96, a COD value of $140.8 \mathrm{mg} / \mathrm{L}$ with a COD: $\mathrm{NO}_{2}{ }^{-}-\mathrm{N}$ ratio of 2.02 was obtained (Figure 6). The ratio exceeds the inhibition limit as described by Tang et al. (2010), therefore decreased in nitrogen removal performance. However, this inhibition process did not occur from the beginning of the study until day 95 of reactor operation. COD concentration was lower than $99.7 \mathrm{mg} / \mathrm{L}$, which could enhanced nitrogen removal via the coexistence of denitrification and anammox (Chen et al. 2016). It assumed that the higher COD concentration was affected by the degradation of bagasse media. This result was supported by Ristianingsih (2018), where 53\% cellulose content in sugarcane bagasse was decomposed during research and caused high levels of COD in reactor effluents. To overcome this obstacle from COD, the influent concentration was increased to $150 \mathrm{mg} / \mathrm{L}$ to compensate for COD, which ranged from 132-158.4 mg/L, so that the COD: $\mathrm{NO}_{2}{ }^{-}-\mathrm{N}$ ratio becomes one.

\section{Conclusions}

Based on these results, the nitrogen removal using anammox process with the Up-flow Anaerobic Sludge Blanket (UASB) reactor can be concluded by the reaction with a stoichiometric ratio of $\Delta \mathrm{NO}_{2}{ }^{-}-\mathrm{N}: \Delta \mathrm{NH}_{4}{ }^{+}-\mathrm{N}$ and $\Delta \mathrm{NO}_{3}{ }^{-}$ $\mathrm{N}: \Delta \mathrm{NH}_{4}{ }^{+}-\mathrm{N}$ was 1.24 and 0.18 , respectively. The highest performance of nitrogen removal obtained by NRR optimum value of $0.29 \mathrm{~kg}-\mathrm{N} / \mathrm{m}^{3}$.d on HRT $12 \mathrm{~h}$ and NLR $0.60 \mathrm{~kg}-\mathrm{N} / \mathrm{m}^{3}$.d. The highest ACE and NRE on HRT 24 $\mathrm{h}$ reached $88 \%$ and $85 \%$, respectively. The anammox pro- 
cess can take place in the area in the temperature range 23$28{ }^{\circ} \mathrm{C}$ using sugarcane bagasse as the organic carrier. The application of sugarcane bagasse could enhance nitrogen removal by provided denitrification process, also could be inhibited at certain COD concentration.

\section{Acknowledgments}

This study was financially supported by Research and Community Service Institute (Lembaga Penelitian dan Pengabdian Masyarakat/LPPM), Universitas Andalas, 2021.

\section{Authors' contributions}

ZLK, PS designed the study. AA carried out the laboratory work. AA, ZLK, PS analyzed the data. AA, ZLK wrote the manuscript. All authors read and approved the final version of the manuscript.

\section{Competing interests}

The author declare that they have no competing interest.

\section{References}

Ahn YH. 2006. Sustainable nitrogen elimination biotechnologies: A review. Process Biochem. 41(8):17091721. doi:10.1016/j.procbio.2006.03.033.

Ali M, Chai LyY, Tang CjJ, Zheng P, Min XbB, Yang ZhH, Xiong L, Song YxX. 2013. The increasing interest of ANAMMOX research in China: Bacteria, process development, and application. BioMed Res Int. 2013(November 2014). doi:10.1155/2013/134914.

Ali M, Okabe S. 2015. Anammox-based technologies for nitrogen removal: Advances in process start-up and remaining issues. Chemosphere. 141:144-153. doi:10.1016/j.chemosphere.2015.06.094.

Allita Y, Gala V, Citra AA, Retnoningtyas ES. 2018. Pemanfaatan ampas tebu dan kulit pisang dalam pembuatan kertas serat campuran. Jurnal Teknik Kimia Indonesia 11(2):101. doi:10.5614/jtki.2012.11.2.6.

Awata T, Oshiki M, Kindaichi T, Ozaki N, Ohashi A, Okabe S. 2013. Physiological characterization of an anaerobic ammonium-oxidizing bacterium belonging to the "Candidatus scalindua" group. Appl Environ Microbiol. 79(13):4145-4148. doi:10.1128/AEM.00056-13.

BPS. 2018. Indonesian Sugar Cane Statistics 2018. Technical report.

Chamchoi N. 2008. Inactivation of ANAMMOX Communities under Concurrent Operation of Anaerobic Ammonium Oxidation (ANAMMOX) and Denitrification. Bioresour Technol. 99:3331-3336.

Chen C, Sun F, Zhang H, Wang J, Shen Y, Liang X. 2016. Evaluation of COD effect on anammox process and microbial communities in the anaerobic baf- fled reactor (ABR). Bioresour Technol. 216:571-578. doi:10.1016/j.biortech.2016.05.115.

Chen Cjj, Huang Xxx, Lei Cxx, Zhu Wjj, Chen Yxx, Wu Wxx. 2012. Improving Anammox start-up with bamboo charcoal. Chemosphere. 89(10):1224-1229. doi:10.1016/j.chemosphere.2012.07.045.

Gao F, Zhang H, Yang F, Qiang H, Zhang G. 2012. The contrast study of anammox-denitrifying system in two non-woven fixed-bed bioreactors (NFBR) treating different low $\mathrm{C} / \mathrm{N}$ ratio sewage. Bioresour Technol. 114:54-61. doi:10.1016/j.biortech.2012.02.113.

Hu Z, Lu X, Sun P, Hu Z, Wang R, Lou C, Han J. 2017. Understanding the performance of microbial community induced by $\mathrm{ZnO}$ nanoparticles in enhanced biological phosphorus removal system and its recoverability. Bioresour Technol. 225(December):279-285. doi:10.1016/j.biortech.2016.11.080.

Jetten MSM, Strous M, Van De Pas-Schoonen KT, Schalk J, Van Dongen UG, Van De Graaf AA, Logemann S, Muyzer G, Van Loosdrecht MC, Kuenen JG. 1998. The anaerobic oxidation of ammonium. FEMS Microbiol Rev. 22(5):421-437. doi:10.1016/S01686445(98)00023-0.

Jin RC, Yang GFF, Yu JJJ, Zheng P. 2012. The inhibition of the Anammox process: A review. Chem Eng J. 197(November 2017):67-79. doi:10.1016/j.cej.2012.05.014.

Jin RC, Zheng P, Hu AH, Mahmood Q, Hu BL, Jilani G. 2008. Performance comparison of two anammox reactors: SBR and UBF. Chem Eng J. 138(1-3):224230. doi:10.1016/j.cej.2007.06.038.

Kumar M, Daverey A, Gu JD, Lin JG. 2016. Anammox Processes. In: Current Developments in Biotechnology and Bioengineering: Biological Treatment of Industrial Effluents. Elsevier Inc. p. 387-407. doi:10.1016/B978-0-444-63665-2.00015-1.

Lackner S, Gilbert EM, Vlaeminck SE. 2014. Fullscale partial nitritation/anammox experiences - An application survey. Water Res. 55(0):292-303. doi:10.1016/j.watres.2014.02.032.

Li J, Qiang Z, Yu D, Wang D, Zhang P, Li Y. 2016. Performance and microbial community of simultaneous anammox and denitrification (SAD) process in a sequencing batch reactor. Bioresour Technol. 218:1064-1072. doi:10.1016/j.biortech.2016.07.081.

Liao D, Li X, Yang Q, Zeng G, Guo L, Yue X. 2008. Effect of inorganic carbon on anaerobic ammonium oxidation enriched in sequencing batch reactor. Journal of environmental sciences (China) 20(8):940-944. doi:10.1016/s1001-0742(08)62190-7.

Lotti T, Kleerebezem R, Lubello C, van Loosdrecht MCM. 2014. Physiological and kinetic characterization of a suspended cell anammox culture. Water Res. 60:114. doi:10.1016/j.watres.2014.04.017.

Ma B, Peng Y, Zhang S, Wang J, Gan Y, Chang J, Wang S, Wang S, Zhu G. 2013. Performance of anammox UASB reactor treating low strength wastewater under moderate and low temperatures. Bioresour Technol. 
129:606-611. doi:10.1016/j.biortech.2012.11.025.

Molinuevo B, García MC, Karakashev D, Angelidaki I. 2009. Anammox for ammonia removal from pig manure effluents: effect of organic matter content on process performance. Bioresour Technol. 100(7):2171-2175. doi:10.1016/j.biortech.2008.10.038.

Nathan AJ, Scobell A. 2012. How China sees America. Foreign Affairs 91(5). doi:10.1017/CBO9781107415324.004.

Oshiki M, Shimokawa M, Fujii N, Satoh H, Okabe S. 2011. Physiological characteristics of the anaerobic ammonium-oxidizing bacterium 'Candidatus Brocadia sinica'. Microbiology. 157(6):1706-1713. doi:10.1099/mic.0.048595-0.

Ristianingsih Y. 2018. Proses Pembuatan Kertas dari Kombinasi Limbah Ampas Tebu dan Sekam Padi dengan Proses Soda. Chempublish Journal 2(2):21-32. doi:10.22437/chp.v2i2.4455.

Strous M, Fuerst JA, Kramer EH, Logemann S, Muyzer G, Van De Pas-Schoonen KT, Webb R, Kuenen JG, Jetten MS. 1999. Missing lithotroph identified as new planctomycete. Nature. 400(6743):446-449. doi:10.1038/22749.

Strous M, Van Gerven E, Zheng P, Kuenen JG, Jetten MSM. 1997. Ammonium removal from concentrated waste streams with the anaerobic ammonium oxidation (anammox) process in different reactor configurations. Water Res. 31(8):1955-1962. doi:10.1016/S0043-1354(97)00055-9.

Tang CJ, Zheng P, Wang CH, Mahmood Q. 2010. Suppression of anaerobic ammonium oxidizers under high organic content in high-rate Anammox UASB reactor. Bioresour Technol. 101(6):1762-1768. doi:10.1016/j.biortech.2009.10.032.

Tsushima I, Ogasawara Y, Kindaichi T, Satoh H, Okabe S. 2007. Development of high-rate anaerobic ammonium-oxidizing (anammox) biofilm reactors. Water Res. 41(8):1623-1634. doi:10.1016/j.watres.2007.01.050.

Tuyen VN, Ryu JH, Yae JB, Kim HG, Hong SW, Ahn DH. 2018. Nitrogen removal performance of anammox process with PVA-SA gel bead crosslinked with sodium sulfate as a biomass carrier. J Ind Eng Chem. 67:326-332. doi:10.1016/j.jiec.2018.07.004.

Van De Graaf AA, De Bruijn P, Robertson LA, Jetten MSM, Kuenen JG. 1996. Autotrophic growth of anaerobic ammonium-oxidizing micro-organisms in a fluidized bed reactor. Microbiology. 142(8):21872196. doi:10.1099/13500872-142-8-2187.

van der Star WR, Abma WR, Blommers D, Mulder JW, Tokutomi T, Strous M, Picioreanu C, van Loosdrecht MC. 2007. Startup of reactors for anoxic ammonium oxidation: Experiences from the first full-scale anammox reactor in Rotterdam. Water Res. 41(18):41494163. doi:10.1016/j.watres.2007.03.044.

Zhang L, Narita Y, Gao L, Ali M, Oshiki M, Okabe S. 2017. Maximum specific growth rate of anam- mox bacteria revisited. Water Res. 116:296-303. doi:10.1016/j.watres.2017.03.027.

Zulkarnaini, Nur A, Ermaliza W. 2019. Nitrogen Removal in the Anammox Biofilm Reactor using Palm Fiber as Carrier in Tropical Temperature Operation. Jurnal Riset Teknologi Pencegahan Pencemaran Industri 10(2):7-15.

Zulkarnaini, Yujie Q, Yamamoto-Ikemoto R, Matsuura N. 2018. One-stage nitritation/anammox process using a biofilm reactor with two-inflow. J Water Environ Nanotechnol. 16(2). doi:10.2965/jwet.17-050.

Zulkarnaini Z, Afrianita R, Putra IH. 2020. Aplikasi Proses Anammox dalam Penyisihan Nitrogen Menggunakan Reaktor Up-Flow Anaerobic Sludge Blanket [Application of Anammox Process in Nitrogen Removal Using Up-Flow Anaerobic Sludge Blanket Reactor]. Jurnal Teknologi Lingkungan. 21(1):31-39. doi:10.29122/jtl.v21i1.3725. 